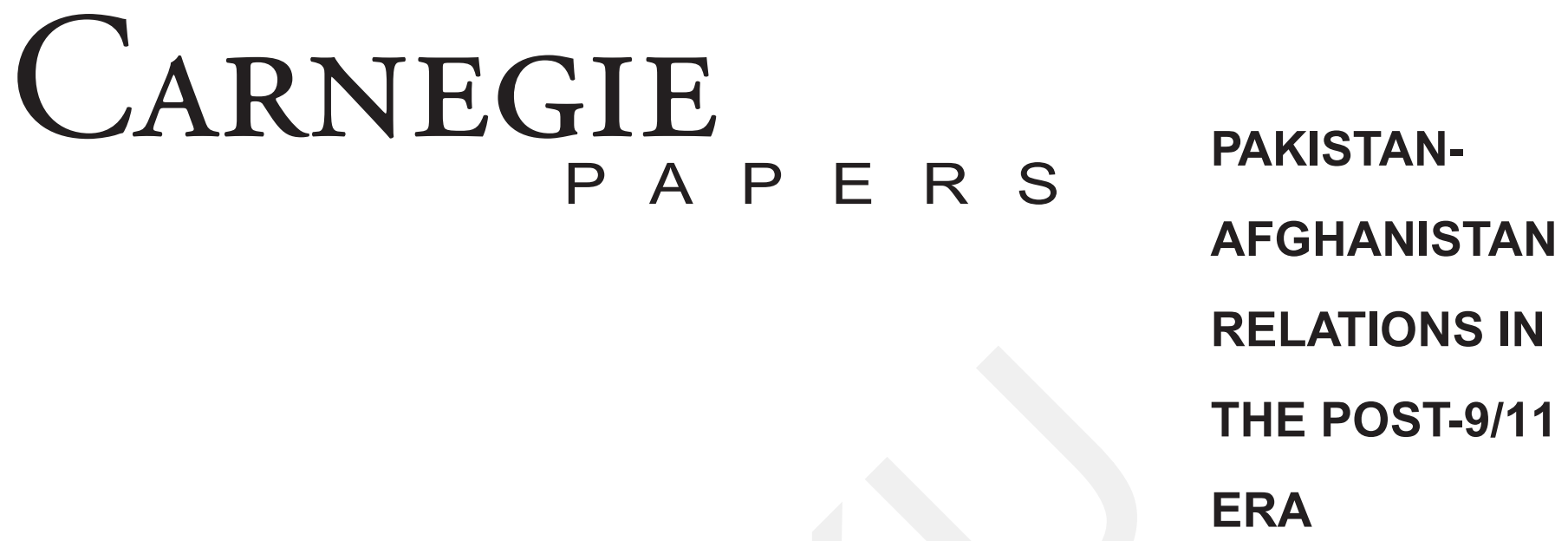

Frédéric Grare

South Asia

Project 
(C) 2006 Carnegie Endowment for International Peace. All rights reserved.

No part of this publication may be reproduced or transmitted in any form or by any means without permission in writing from the Carnegie Endowment. Please direct inquiries to:

Carnegie Endowment for International Peace

Publications Department

1779 Massachusetts Avenue, NW

Washington, DC 20036

Phone: 202-483-7600

Fax: 202-483-1840

www.CarnegieEndowment.org

This publication can be downloaded for free at www.CarnegieEndowment.org/pubs. Limited print copies are also available. To request a copy, send an e-mail to pubs@CarnegieEndowment.org.

\section{Carnegie Papers}

Carnegie Papers present new research by Endowment associates and their collaborators from other institutions. The series includes new time-sensitive research and key excerpts from larger works in progress. Comments from readers are most welcome; please reply to the author at the address above or by e-mail to pubs@CarnegieEndowment.org.

\section{About the Author}

Frédéric Grare is a visiting scholar with the Carnegie Endowment for International Peace, where he assesses U.S. and European policies toward Pakistan and focuses on the tension between stability and democratization in Pakistan, including challenges of sectarian conflict, Islamist political mobilization, and educational reform. Grare is a leading expert and writer on South Asia, having served most recently in the French Embassy in Pakistan and, from 1999 to 2003, in New Delhi as director of the Centre for Social Sciences and Humanities. Grare has written extensively on security issues, Islamist movements, and sectarian conflict in Pakistan and Afghanistan and has edited the volume India, China, Russia: Intricacies of an Asian Triangle. 


\section{CONTENTS}

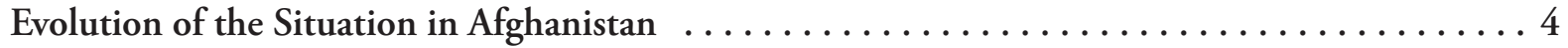

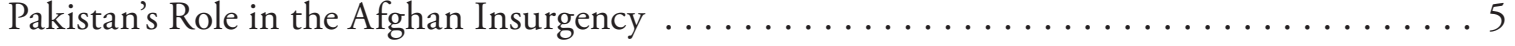

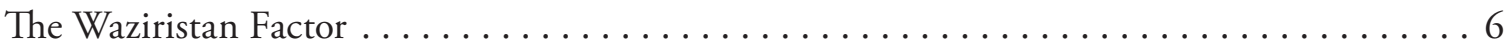

Afghanistan through Pakistan's Eyes $\ldots \ldots \ldots \ldots \ldots \ldots \ldots \ldots \ldots \ldots \ldots \ldots \ldots \ldots$

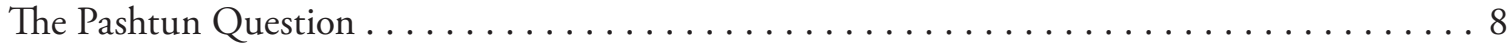

Bilateral Relations and Domestic Politics . . . . . . . . . . . . . . . . 11

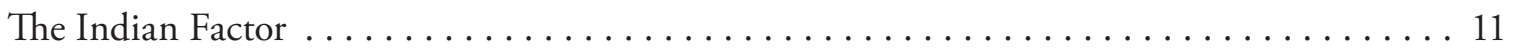

Securing U.S. and International Support $\ldots \ldots \ldots \ldots \ldots \ldots \ldots \ldots \ldots \ldots \ldots \ldots \ldots \ldots \ldots \ldots \ldots \ldots$

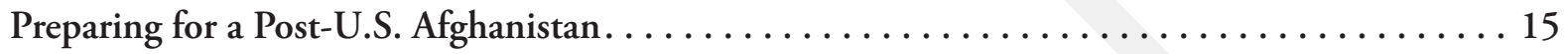

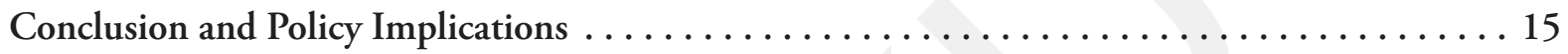

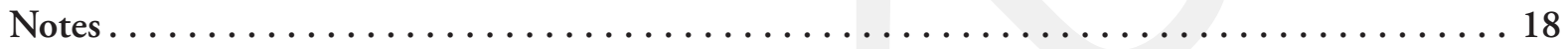


p 
Taliban insurgents and their Al Qaeda allies, once thought defeated in Afghanistan, are regaining strength. Regrouped and reorganized, better equipped and financed, and more sophisticated tactically, they are threatening both the reconstruction process and the U.S.-led coalition forces on the ground. According to the U.S. Department of Defense, sixty-six U.S. troops were killed in combat in Afghanistan in 2005, more than in the previous four years combined. ${ }^{1}$

Pakistan-Afghanistan relations have been another casualty of the renewed violence. The resurgence of the Taliban movement and the growing insurgency in the provinces bordering the Pakistan-Afghan border have once again generated tensions between Kabul and Islamabad. The two countries are accusing each other of interfering in their respective domestic affairs. Afghanistan blames Pakistan for fueling the insurgency in Afghanistan in order to destabilize the government of Hamid Karzai and install a more compliant government in Kabul. President Karzai himself criticized Pakistan on several occasions, claiming Pakistan was training militants and sending them over the border. ${ }^{2}$ In turn, Islamabad blames Kabul for its alleged support to the Baloch guerrillas and the situation in Waziristan.

Relations between the two countries have never been easy. Despite the support given by Pakistan during the jihad against the Soviet Union, suspicion runs deep in the minds of leaders of both countries. Afghanistan was the only country to vote against Pakistan's accession to the United Nations after its independence because of Kabul's claim on the Pashtun territories located on the Pakistani side of the Durand Line. This claim quickly generated a quasi alliance between Kabul and New Delhi, and Islamabad seized the occasion of the Soviet invasion to try to reverse this situation. By supporting the seven parties of the Afghan resistance and later the Taliban, Pakistan expected to install a friendly government in Kabul. The attempt backfired.

The situation since September 11, 2001, is both very similar to and very different from the one that prevailed before the attacks on the World Trade Center and the Pentagon. The Afghan claim on Pakistan's Pashtun territories persists, and Kabul still refuses to recognize the Durand Line as the international border between the two countries. But now the new Afghan government is backed by the United States and, officially at least, by the entire international community, and Pakistan is once more caught in a dilemma. It still cannot satisfy Afghan claims and yet is officially a key ally in the war on terror that motivated the U.S. intervention in Afghanistan and the overthrow of the Taliban government. This dilemma creates a major and permanent tension in Islamabad's foreign policy, which needs to reconcile its bilateral and regional objectives with the absolute necessity to preserve and constantly reassert its strategic value to the United States.

Thus, there is a large asymmetry of interests between Afghanistan and Pakistan. What is essentially a bilateral issue for Kabul goes far beyond the Pashtun question for Islamabad. For Islamabad, Afghanistan is one element in a larger game: not only is Afghanistan part of its Indian policy, but it is also to some extent a component of its global standing. 
The persistence of tensions between Pakistan and Afghanistan should be a source of concern for the West. Although Pakistan alone should certainly not be held responsible for the deterioration of the Afghan internal situation - the source of which is domestic — nor primarily for the current insurgency, Pakistan nevertheless contributes actively to the insurgency and thus threatens the international reconstruction effort. The Taliban, backed by Pakistan, are not today in a position to unseat the government, yet they continue to be a threat in an increasingly large part of the country.

The stakes are numerous: First and most important are the ordinary Afghan citizens whose daily lives have been affected by almost thirty years of conflict and whose security continues to be under constant threat. This insecurity also prevents development from taking place, which in turn reinforces insecurity and increasingly pushes Afghanistan in a downward and dangerous spiral. The possibility of Afghanistan once again becoming a sanctuary for terrorism and a threat to the larger international community is also a serious issue.

Pakistan also has legitimate concerns of its own. Understandably, it cannot accept a permanent threat to its territorial integrity and, rightly or wrongly, feels increasingly encircled by India and India's regional allies. For the United States, more specifically, the return of the Taliban, or even simply their persistent hostile presence along the Pakistan-Afghan border, would jeopardize the stated U.S. objective of opening up former Soviet Central Asia through Afghanistan and Pakistan and eventually linking it up with India. Normalization of relations between Afghanistan and Pakistan is therefore both a regional and a global imperative.

\section{EVOLUTION OF THE SITUATION IN AFGHANISTAN}

Afghan recriminations do not necessarily mean that Pakistan is primarily responsible for the ongoing Afghan insurgency. The possibility that accusations of interference may also serve domestic political purposes may be partly true. All Afghans, whatever their ethnic or political affiliation, view the domestic situation as the main cause of the insurgency. Most believe that President Karzai has promised too much to everyone and is now unable to deliver.

After the Taliban government was toppled, many supported the Karzai government in the hope that it would guarantee their physical security and improve their economic condition. The situation improved in the northern part of the country, but this was not the case in most of the rest of the country. In many parts of Afghanistan people do not see the dividends of peace, including in some stable and peaceful provinces such as Bamian, where almost no development work is taking place. ${ }^{3}$ Poor governance and endemic corruption remain key issues all over the country while drugs provide antigovernment elements with autonomous sources of revenue while perverting governance from the inside.

This situation, added to the security problem in many parts of the country, is alienating large parts of the population from the reconstruction process. People's concerns are legitimately centered on the preservation of their own lives. No matter how unreasonable some expectations may have been, and notwithstanding the difficulties of the reconstruction process, the Afghan government is also partly responsible for the current deteriorating situation in the country. Pakistan is correct in asserting that Afghanistan is also trying to place the blame for its own failure on its neighbor. 


\section{Pakistan's Role in the Afghan Insurgency}

Yet Pakistan's partial responsibility in the ongoing insurgency remains. The Afghan government has repeatedly accused Islamabad of not only sheltering the Taliban but also helping them in order to make its presence and indispensability felt. On June 22, 2006, President Karzai went even further, although indirectly, by both criticizing the fact that the fight against the Taliban was conducted exclusively on Afghan soil and asking the international community to disarm the terrorists by cutting their sources of funding and attacking their training camps, implicitly pointing to Pakistan.

During recent months, the Pakistani government has of course strongly denied any involvement, arguing that any destabilization of Afghanistan would negatively affect Pakistan and Pakistanis and insisting that, far from trying to destabilize President Karzai, Pakistan helped him get elected. Pakistan's interior minister, Aftab Ahmed Khan Sherpao, even proposed on March 9, 2006, to fence the border with Afghanistan and plant land mines to stop the infiltration of foreigners. ${ }^{4}$ It is therefore necessary to examine the validity of the arguments of both parties to the dispute in light of the actual facts and logic of the situation.

The proposal to fence the border does not constitute proof of Pakistan's goodwill. With or without land mines, fencing the border is not a practical solution as it would have to be complemented by effective fire and observation. Given the length of the border, it would require more troops than Pakistan has at its disposal.

As noted by Marvin Weinbaum, Pakistan indeed "refrained from serious interference in Afghanistan's October 2004 presidential election"; 5 in fact, Pakistan helped with the organization of the vote in refugee camps. Pakistan did not try "to influence the outcome of individual contests in the September 2005 parliamentary vote." ${ }^{6}$ It is also undeniable that Pakistan's commercial interests are better served by a stable Afghanistan.

Yet, one cannot refrain from noting that the insurgency is taking place essentially in a corridor 35 miles wide along the border between Afghanistan and Pakistan, across the provinces of Konar, Nangarhar, Paktia, Paktika, Zabol, Kandahar, and Helmand. The guerrillas could not operate without the benefit of sanctuaries in Pakistan. Islamabad rightly argues that it cannot control a border that it has proposed to fence. Fencing the border is of course totally impractical and has been described as such by a former director general of Pakistan's Inter-Services Intelligence (ISI), Lieutenant General Asad Durrani, who said, in addition, that cross-border movement could not be controlled, whatever the number of troops. ${ }^{7}$ Durrani's argument is undoubtedly valid, but the fact is that most attacks are carried out in southern Afghanistan by Taliban coming from Pakistan's Quetta district.

Some witnesses also claim that Pakistan's role is not only passive. They say that militants are brought from the Quetta district to the Afghan border by Pakistani military trucks. Senior lieutenants to Taliban chief Mullah Omar are said to operate from Quetta, from where they run military operations in the south-central Afghan provinces of Helmand, Kandahar, Oruzgan, and Zabol. ${ }^{8}$ Moreover, Gulbuddin Hekmatyar is particularly active in the Konar, Nangarhar, Kapisa, Laghman, and Nurestan provinces and recently declared his allegiance to the Taliban before retracting his statement. According to local residents, Hekmatyar seems to be a regular visitor to Peshawar where, according to Robert Kaplan, he has his headquarters as well as to the Bajaur agency in Pakistan's Federally Administered Tribal Areas.' 
Finally, a recent accusation by Colonel Chris Vernon, ${ }^{10}$ British chief of staff for southern Afghanistan, who declared that "the thinking piece of the Taliban is out of Quetta," which he described as the major headquarters of the movement, confirmed not only a number of previous Afghan statements but also statements of local witnesses who denounce army actions in their own districts and U.S. counterterrorism officials who had previously declared that parts of Pakistan were a safe haven for terrorists. ${ }^{12}$ In July 2006, the press agency Reuters announced that the British government had banned the Baloch Liberation Army and that "scores of Taliban had been arrested in a crackdown," including Mullah Hamdullah, a former commander of Taliban forces in the southern province of Helmand, where British troops have met fierce resistance since their deployment. ${ }^{13}$ This confirmed what had been said for months by local observers and denied by the Pakistani government.

\section{The Waziristan Factor}

All statements implying direct or indirect Pakistani responsibility for the situation in Afghanistan have been refuted by the Pakistani government. Accusations from President Karzai in particular have been flatly dismissed by Pakistan's Ministry of Foreign Affairs, which declared that the charges showed only the Afghan failure. ${ }^{14}$ Op-eds in the Pakistani press also suddenly multiplied after President Karzai's visit to Pakistan to demonstrate the supposed invalidity of the argument. ${ }^{15}$

More interesting is the argument put forward by the Pakistani government that its actions in Waziristan, the tribal agency where some eighty thousand Pakistani troops have been mobilized, are proof that Islamabad is doing whatever it can to stop the fundamentalist insurgency from spilling over into Pakistani territory, thus possibly causing Pakistan itself to become a victim of the Taliban.

Pakistani difficulties in Waziristan are real. Approximately 450 Pakistani soldiers have already been killed there, fighting the local Taliban and members of Al Qaeda. Cities like Miranshah (also called Miram Shah) and Mirali are virtually under Taliban control. Three years of military campaigning have not only failed to eliminate foreign militants but also reinforced the local Taliban.

An examination of Waziristan's recent history offers a slightly different picture of the problem and raises a number of questions. When the coalition forces moved into Afghanistan in October 2001, the attack came from the northern part of the country. The military rationale was to sandwich $\mathrm{Al}$ Qaeda and the Taliban to eliminate them. It was therefore imperative to close the borders as much as possible, including the border of Afghanistan with Pakistan's Khyber agency. In Waziristan, however, the Miranshah and Mirali routes were left open. If, understandably, not all borders could be sealed, these two routes should have been, as they were well known for having been intensively used by the mujahideen during the jihad against the Soviets. Keeping them open was therefore a deliberate move on the part of a military establishment that had been forced to make a U-turn in its Afghan policy only a few weeks earlier. Both Taliban and foreign fighters were welcomed in Waziristan by the local Taliban, some of whom apparently made a fortune by sheltering foreign combatants, Uzbeks in particular. During this period only minor cadres of Al Qaeda were captured and delivered to the Americans.

This policy changed in 2002 when increasing U.S. pressure forced a reluctant Islamabad to send regular army troops into South Waziristan to check the influx of the Taliban and Al Qaeda remnants fleeing the U.S.-led operation Anaconda in southeastern Afghanistan. It came as a surprise to local Taliban, who were asked by Pakistan's intelligence agencies to surrender foreign militants to the 
authorities, thus drawing a clear line between the two. Military operations in South Waziristan started in February 2004 when the U.S. military complained that the territory was not just a hideout for Al Qaeda and Taliban fighters but also a launching pad against allied troops in Afghanistan. ${ }^{16}$

Even after December 2005, when the first signs of a Taliban-like resurgence started to emerge, Pakistani military and civilian authorities looked the other way and did nothing to stop the militants. According to the magazine Newsline, "the administration was under clear instructions not to impede the movements of the local Taliban who remained unchecked and continued to consolidate their position in the area." ${ }^{17}$

In fact, the relative proximity of the militants' hideouts, the paramilitary forces' check posts, units of regular troops, and even the military intelligence agencies leads many observers to suspect that Pakistani authorities are cooperating with the Taliban. ${ }^{18}$ The Pakistani government is not only turning a blind eye to Taliban activities but also intervening to protect Taliban commanders that serve Pakistani objectives in Afghanistan. "The current operation is only directed against the Taliban foot soldiers of local origin, led by insignificant leaders, whereas places like Shawal from where top Afghan Taliban commanders such as Jalaluddin Haqqani and Mullah Akhtar Mansoor, are still organizing guerilla raids against Afghanistan, remain calm and quiet." ${ }^{19}$ As a result, Taliban based in Waziristan continue operations in Kabul and the Afghan eastern regions of Khowst, Lowgar, Paktia, and Paktika. ${ }^{20}$

Although the Afghan government would like to convince the international community otherwise, the situation in Waziristan is perhaps not as one-sided as one may think at first sight. Pakistan's government has on several occasions asked its Afghan counterpart to do more to stop cross-border infiltrations from Afghanistan. In February 2006, on the eve of the Afghan president's visit to Pakistan, Prime Minister Shaukat Aziz expressed his dissatisfaction in the face of what he considered an insufficient effort on the part of Afghanistan. ${ }^{21}$ Pakistani officials insist that the Taliban ranks have been infiltrated by anti-Pakistan elements deputed to Pakistan territory to fuel the backlash of the Pakistani territory. ${ }^{22}$

The information, if proved, does not necessarily absolve Pakistan of double-dealing. Kabul did, for months, send signals to Islamabad that it too had nuisance capabilities in Pakistani territory and could use the Pashtun question for its own benefit. On February 17, 2006, President Karzai himself led a forty-member delegation to the funeral of the Pashtun nationalist leader Abdul Wali Khan. ${ }^{23}$ During a press conference on the same day, Karzai warned that "Iran and Pakistan and others are not fooling anyone." He further declared:

If they don't stop, the consequences will be ... that the region will suffer with us equally. In the past we have suffered alone; this time everybody will suffer with us.... Any effort to divide Afghanistan ethnically or weaken it will create the same thing in the neighboring countries. All the countries in the neighborhood have the same ethnic groups that we have, so they should know that it is a different ball game this time. ${ }^{24}$ 


\section{AFGHANISTAN THROUGH PAKISTAN'S EYES}

The real question is not whether Pakistan is or is not supporting the Taliban, but why it is doing so.

Afghan officials have their own views of Pakistani motivations, which include Pakistan's willingness to pressure Afghanistan for the recognition of the Durand Line and Pakistan's historical paranoia. According to the Afghans, Pakistan fears a stable Afghanistan because it would revitalize the Pashtun issue and establish a reverse alliance with India. Afghans also perceive Pakistan as an archaic power, willing to control Afghanistan through a physical presence in the country.

These assertions contain an element of truth but focus almost exclusively on the bilateral aspect of the relationship. Reasons for Pakistan to intervene in Afghanistan are larger and more ambiguous than commonly asserted. They range from the need to exert pressure on the Karzai government to force it to sign an agreement on the border question to the perceived necessity for signaling to the international community that no settlement of the Afghan problem can be obtained without Islamabad's interests being taken into account. Moreover, Islamabad most probably keeps its options open for the day that the United States and, subsequently, its European and Australian allies, will leave.

It is not clear whether the Pakistani government has yet identified its final objective in Afghanistan. Islamabad seems at the moment to be elaborating a series of options that it will use according to the evolution of the situation. The motivations of Pakistan's Afghan policy cannot be reduced to the Pashtun question alone; they should be sought within the structure of the South Asian security complex. Afghanistan is only one component of Pakistan's Indian policy. The search for Pakistan's motivations also must take into account the evolution of U.S. policy in South Asia, characterized by the ongoing rapprochement with India. Fear of being internationally marginalized is undoubtedly an important component of Islamabad's foreign policy in Afghanistan.

\section{The Pashtun Question}

The Pashtun question is multidimensional. It is an ethnic, political, and geopolitical problem. It is at the core of Afghan nationalism but also reflects, although to a much lesser extent, the difficulties of nation building in Pakistan itself. Both Pashtun and non-Pashtun elites have instrumentalized it in the two countries, although in a contradictory manner, for domestic political purposes. Both countries (not only Pakistan) have been trying to promote adversarial relations between Pashtuns and other ethnic groups. Academics often cite Islamabad's favoritism toward the Pashtun mujahideen, in particular Gulbuddin Hekmatyar, against other anticommunist parties during and after the anti-Soviet jihad as well as Pakistan's support to the largely Pashtun Taliban movement after 1994. They tend to forget that from independence in 1947 until today Kabul has constantly sent signals to Islamabad indicating that the Pashtun community on the Pakistani side of the Durand Line was not only a population that Afghanistan considered its own but also a strategic asset that, rightly or wrongly, Kabul thought it could use in its relations with Islamabad.

The Pashtun question has been a source of tension between Pakistan and Afghanistan since the creation of the "land of the pure" in 1947. Afghanistan never recognized the Durand Line as an international border. The return to Afghanistan of the Pashtun areas situated on the Pakistani side of the Durand Line has always been and still remains an Afghan demand. The July 1947 referendum 
offered no choice to the Pashtuns of the North-West Frontier Province (NWFP) other than to become part of either India or Pakistan.

Afghanistan has always stated that the 1947 referendum did not satisfy the requirement for self-determination because a substantial part of the Pashtuns boycotted the vote and the referendum was a unilateral step taken without Afghan consultation or consent. Afghanistan further argued that "Pakistan was not a successor state to Britain but a new state carved out of British India." 25 Whatever treaty rights existed were therefore extinguished.

Afghans have maintained this position, irrespective of who has been in power in Kabul. Zahir Shah, king of Afghanistan; President Muhammad Daoud, who deposed Zahir Shah; and the successive Communist leaders all maintained the old Afghan claim on "Pashtunistan." The Pashtunistan issue became the principal source of dispute with Pakistan, although its intensity has varied over time. On one occasion only, when it appeared that the Afghan opposition was establishing its bases on the Pakistan side of the Durand Line, did the first Communist leader of Afghanistan, Noor Muhammad Taraki, propose to Pakistan's military dictator Zia ul-Haq that Afghanistan would recognize the Durand Line as the international border between the two countries if Pakistan stopped helping the mujahideen. ${ }^{26}$

Pakistan's position was of course always the opposite. Islamabad has always considered the Durand Line a valid international boundary that has been recognized as such on several occasions by the Afghan authorities. ${ }^{27}$

Islamabad, however, has always been careful in its dealings with Afghanistan never to antagonize Pashtuns, both domestically and in Afghanistan. On the eve of the Soviet invasion of Afghanistan, following the Pakistan government's long tradition of co-option, the dictator Zia ul-Haq offered Abdul Wali Khan, the historic leader of the Pakistani Pashtuns, the post of prime minister at the head of a government controlled by the army, hence making the Pashtun question manageable both politically and militarily.

The Soviet invasion of Afghanistan gave Pakistan the opportunity to rethink its Afghan policy. Islamabad tried to play both the Pashtun and Islamist cards. Out of the seven resistance parties sponsored by Pakistan, six were Pashtun. Only the Jamiat-i-Islami led by Burhanuddin Rabbani and Ahmad Shah Massoud had a Tajik majority. However, the most effective organizations were Islamist. Pakistan expected that Islamist groups would be able to transcend ethnic divisions and denounce the traditional Afghan claim on Pashtunistan.

Pakistan laid the foundation of a new relationship between the two countries by compelling the Afghan refugees to affiliate themselves with the Islamist parties operating from Peshawar and by manipulating the resistance through arms deliveries. The former buffer state between the Russian and British empires had become the de facto strategic depth of the newly created Pakistan. The Soviet withdrawal allowed Pakistan's military leadership to transform Afghanistan into Pakistan's strategic depth vis-à-vis India. Although this new concept made little, if any, military sense, it clearly indicated Pakistan's willingness to control its turbulent neighbor.

The tools of this policy varied over time. The motivations behind Pakistan's backing of the Taliban, for example, were no different from the motivations that had led Islamabad to back Gulbuddin Hekmatyar. When it became obvious that Hekmatyar would neither be able to seize Kabul nor recognize the Durand Line, Pakistan simply shifted its support to the Taliban. 
Pakistan quickly understood that it could exploit what was essentially a Pashtun movement capitalizing on the rejection of the political parties blamed by the vast majority of the population for the growing instability of the country. Pakistan's leaders thought that the ideology of the Taliban movement would eventually help transcend Afghan ethnic divisions. But Pakistan was once more disillusioned. Despite Islamabad's support, the Taliban did not accept the Durand Line as the international border and could not mobilize the population beyond their own ethnic base. Instead, Afghanistan became more ethnically polarized.

September 11, 2001, marked a temporary reversal in Pakistan's strategy toward Afghanistan but not the end of the Pashtun question. If Pakistan could not obtain satisfaction on the Durand Line, a friendly Pashtun government in Kabul was still preferable to any of its alternatives, which had accumulated years of resentment toward Pakistan and would be even less compliant. Islamabad's efforts proved futile. Until the U.S. intervention, Pakistan tried to save the Taliban by attempting to convince its leaders to hand over Osama bin Laden. It offered a channel for negotiations up until the outbreak of war, when the Afghan ambassador to Pakistan was arrested and handed over to the United States. ${ }^{28}$

The Pashtun question and more specifically the Durand Line issue remain sensitive topics in Afghanistan. Pashtuns are on the defensive. Some perceive Uzbeks and Hazaras as gaining ground and feel excluded from the political and economic reconstruction process. ${ }^{29}$ For them, renouncing the reunification of the Pashtuns from both sides of the Durand Line would signify accepting the gradual marginalization of the Pashtuns. Non-Pashtun leaders in Afghanistan are not more forthcoming on the recognition of the Durand Line. In a political scene still dominated by the Pashtuns, nobody can take the risk of affronting Pashtun sentiment. Leaders of the Northern Alliance also see the issue as a means of pressuring Pakistan.

Pakistan claims, probably rightly, that the Pashtun nationalists' expectations are ill founded and that, if given the choice between Pakistan and Afghanistan, Pakistani Pashtuns would decide to remain citizens of Pakistan.

Yet the Pakistani government remains careful to manage Pashtun sentiment. Since Pakistan's independence, the NWFP is the only province of the country not to be named for its ethnic majority. The proposal for naming it "Pashtunistan" has been refused by all successive Pakistani governments. True, the label covered different realities: For the Pashtuns living in Pakistan, the word meant no more than the present NWFP; for the Afghan government, it covered a much larger area comprising the NWFP and Balochistan. In the most extravagant meaning of the word, upheld by Pashtuns living outside Pakistan, Pashtunistan extends from the Indian Ocean to Gilgit in Pakistan's Northern Areas and from the Durand Line to the Kashmir border. ${ }^{30}$

Starting in 1997, the Pakistani Pashtun nationalist leadership, which lost a great deal of its popular appeal after the Soviet invasion when it initially supported the Afghan Communist government, proposed the term "Pushtunkwa." The term was unequivocal and designated exclusively the NWFP, but the Pakistani authorities did not consider it more acceptable.

On May 19, 2006, during an interview with a private Pashto-speaking television channel, General Pervez Musharraf declared that the NWFP could be named Khyber. ${ }^{31}$ This proposal still fell short of accepting a direct link between the name of the province and its ethnic majority, but it was significant on several counts. It seemed to indicate that the regime was confident enough to allow the use of a more symbolically charged name. It was also clearly meant to seduce Pakistani Pashtun 
nationalists. They are part of the grand alliance that the government is preparing for the upcoming elections, and they enjoy privileged relations with the Afghan authorities. The Pakistani government is not taking their loyalty for granted.

\section{Bilateral Relations and Afghan Domestic Politics}

Since 9/11 Pakistan has had to give up the idea that it could install Afghan leaders of its choice and dictate foreign policy to Kabul. Yet, as noted by Marvin Weinbaum:

... [T] o retain influence, Pakistan has instead chosen to rely on its ... networks with Pashtun leaders... It backs certain Pashtun regional political figures, some of them opposed to the central government, and has endorsed Pashtun claims of being disadvantaged in the distribution of government offices and development funds. ${ }^{32}$

After 9/11, Pakistan initially insisted on the inclusion of "moderate" Taliban leaders in any new government as a price for its support in the war on terrorism. ${ }^{33}$ However, the Northern Alliance, Russia, and Iran firmly opposed any Taliban role. Many Afghans saw Islamabad's insistence on greater Pashtun representation as a new form of the same old strategic design. ${ }^{34}$

A transitional administration was formed after the emergency Loya Jirga in June 2002, and it included a number of ministers (Mohammad Qasim Fahim, Abdullah Abdullah, and Younus Qanuni) from the former Northern Alliance. Despite fourteen ministerial portfolios, Pashtuns felt marginalized.

The demographic logic of the democratic process played in favor of Pakistan. Pashtuns expected the imbalances to be redressed by means of the 2005 elections. They ultimately won 113 seats out of 243. The most prominent non-Pashtun figures of the Northern Alliance were gradually replaced by Pashtun parliamentarians.

For Pakistan, playing on Pashtuns' insecurities was an easy game. The end of Taliban rule had made many Pashtuns a target for the other communities, and Pakistan could present itself, not without justification given its own generosity with Pashtun refugees, as a protector of the Pashtuns.

\section{The Indian Factor}

The Indian factor focuses Pakistan's perception of Afghanistan and its policies there. From independence until 1992, India supported whatever government was in power in Kabul. The Pashtunistan issue offered India the possibility of trapping Pakistan between two fronts in the event of a clash along the Durand Line and along the India-Pakistan border. Things changed after 1992 when the Pakistan-backed mujahideen entered Kabul. Soon, however, internal fighting led to a split between Gulbuddin Hekmatyar and all other parties. India then supported whoever opposed Pakistan.

Even after the fall of Kabul to the Taliban, in September 1996, New Delhi took fifteen days to express its shock at the execution of former Afghan president Najibullah. India then continued to support President Burhanuddin Rabbani but, for the first time in the history of its relations with Afghanistan, found itself supporting an opposition group and not the Afghan government. India soon became a solid supporter of the Northern Alliance. 
With such a background, India's return to the Afghan scene was bound to worry Pakistan. India and Pakistan soon started trading charges of sabotage and terrorism. The opening of Indian consulates in Afghanistan, in particular, became a bone of contention between the two countries. On July 27, 2003, Pakistan's government officially expressed its "deep" concerns about the Indian government's activities along the Pakistan-Afghan border. ${ }^{35}$ Pakistan started accusing the Indian consulates of having "less to do with humanitarian aid and more to do with India's top-secret intelligence agency, the Research and Analysis Wing." ${ }^{36}$ Pakistan's allegations about India ranged from charges of printing false Pakistani currency to carrying out acts of sabotage and terrorism on Pakistani territory. Pakistan has accused India of setting up networks of "terrorist training camps" located inside Afghanistan, including at the Afghan military base of Qushila Jadid, north of Kabul; near Gereshk, in southern Helmand province; in the Panjshir Valley, northeast of Kabul; and at Kahak and Hassan Killies in western Nimruz province. ${ }^{37}$ On September 1, 2003, the Indian consulate in Jalalabad was attacked. Kabul's categorical assurances that it would not allow any anti-Pakistani activities on its soil failed to satisfy Pakistan.

Mutual recriminations increased with the beginning of the insurgency in Pakistan's Balochistan province. After claiming for months that the Balochistan Liberation Army was a myth, the chief minister of the province, Jam Muhammad Yusuf, suddenly declared on August 13, 2004, that the Indian secret services were maintaining forty terrorist camps all over Baloch territory. ${ }^{38}$ From then onward, whenever convenient, the Pakistani press kept reiterating the accusations, claiming that proof had been found of the Indian consulates' involvement in Balochistan's troubles.

In May 2003, Pakistan launched more accusations against India, accusing India of fomenting troubles in Waziristan, where the Pakistani army was meeting significant resistance from the local Taliban and Al Qaeda. Speaking on condition of anonymity, an official declared that Pakistan had collected "all required information about the involvement of India in fomenting unrest in North and South Waziristan," ${ }^{39}$ suggesting that "the Indian consulates in Southern Afghanistan have been supplying money as well as arms and ammunition to the militants that has added to the trouble and violence in the tribal belt." ${ }^{30}$

Both accusations were reiterated officially at the beginning of July 2006 by Senator Mushahid Hussain, chairman of the Senate Standing Committee on Foreign Affairs, who stated that "RAW [Research and Analysis Wing] [is] training 600 Baluchis in Afghanistan,"“1 insisting that "India [is] propping up the Baloch war" ${ }^{\prime 2}$ and denouncing the implication of the Riyast-i-Amniyat-i-Milli, the Afghan intelligence agency, and of Afghan border security forces officials in connection with RAW. ${ }^{43}$

These accusations are logically difficult to prove or refute. Not only did India manage to maintain friendly relations with all Afghan governments until the fall of Najibullah's government and its replacement by a Pakistan-backed mujahid in 1992, but it had also previously welcomed, armed, and equipped Baloch insurgents at the end of the 1970s.

India and Pakistan are again fighting an emerging proxy war in still war-torn Afghanistan. The real question is not whether it is happening but its actual intensity. The recent killing of an Indian engineer by the Taliban, for example, has been interpreted in India as a Pakistani attempt to discourage the Indian presence in the country. There is little doubt that India has a strong intelligence presence in Afghanistan, but this does not necessarily mean it is conducting special operations. But even if it does so, are they militarily significant? The local situation in both Waziristan and Balochistan has been such that Pakistan would have been in trouble in the two areas, 
irrespective of whether India (or Afghanistan) engaged actively in subversive operations in these regions. Even the basis of the Pakistani accusation - the proximity to the Pakistan-Afghan border of Indian consulates in Jalalabad and Kandahar-is questionable. The former director general of ISI, Lieutenant General Asad Durrani, noted that Pakistani intelligence should be able to monitor Indian activities given the intensity of Pakistan's own presence in the area. ${ }^{44}$

Pakistan has gone as far as accusing India of placing troops in Afghanistan. Senator Mushahid Hussain had already spoken, on May 14, of India increasing the number of its military personnel in Afghanistan on the pretext of providing security to the Border Roads Organization, indicating that the strength of Indian troops "had reached almost a company size." ${ }^{45}$ At the beginning of July 2006, however, the Pakistani press started speaking of "unconfirmed reports about an Indian decision to send peacekeeping troops to Afghanistan at the instance of the United States, NATO and the European Union." ${ }^{46}$ The Pakistani newspaper The Nation reported on the contrary that, although India was keen to deploy its troops in Afghanistan under the coalition command, the United States and NATO had assured Pakistan that they would not entertain any such request by New Delhi. ${ }^{47}$

It is reasonable to assume that the last thing that Pakistan would like to see is an Indian presence on both its eastern and western borders. Pakistan quite naturally will not allow any other regional neighbor of Afghanistan, in particular India, to gain a preponderance of influence in Afghanistan. Pakistan's interest is vital at a time when India's growing political, military, and economic ties with both Afghanistan and the United States lead many Pakistanis to believe their country is being marginalized.

\section{Securing U.S. and International Support}

The Indian factor explains only partially Pakistan's interventionism. Pakistan's attitude in Afghanistan is essentially the result of its fundamental security dilemma. Too weak to confront India directly, Pakistan needs to avoid isolation and maintain international engagement at all costs. In particular, it constantly seeks U.S. protection, which it has never been able to formalize through a bilateral treaty. This protection can be granted only on a case-by-case basis, depending on the particular circumstances. It is up to Pakistan to preserve its status as a frontline state for as long as possible, according to the strategic priorities of the moment.

When the Soviet Union invaded Afghanistan, Pakistan emphatically fought it. Yet Pakistan also was reluctant to have the conflict end and the United States leave, taking its pocketbook with it.

Today's situation is both very similar and very different. Pakistan is again considered a frontline state in the war on terror since its U-turn of September 12, 2001, in Afghanistan. Cooperating in fighting terrorism is the basis for a renewed alliance with the United States. However, Pakistan is now competing with its traditional enemy, India, for the status of preferential ally of the United States. The two South Asian countries are also competing for influence in Afghanistan itself, a competition that can be neutralized only by a strong U.S. presence.

Pakistan's activism therefore sends a somewhat contradictory message. On the one hand, it intends to signal the international community, and the United States in particular, that Pakistan is still a player in Afghanistan. Neither the partial de-hyphenation of relations between the United States and Pakistan on the one side and the United States and India on the other nor the obvious preference for India expressed by the India-U.S. civilian nuclear deal can change that. 
On the other hand, Pakistan also needs the international community. Although it does not say so, Pakistan would logically feel more comfortable with a prolonged NATO presence in its neighborhood. This presence would guarantee that no regional power, in particular India, could acquire a dominant influence in Afghanistan at the expense of Pakistan's perceived national interests.

There is therefore a real degree of ambivalence in Pakistan's support to the Taliban. Islamabad's objectives may differ from the Taliban's. Some Taliban members have already stated that their "aim is clearly to discourage the North Atlantic Treaty Organization [from] deploy[ing] troops in Southern Afghanistan." ${ }^{48}$

Islamabad's brinkmanship is not without risks. A growing number of regional powers-Iran, Russia, and some Central Asian states - increasingly resent the U.S. and NATO presence in Afghanistan, for reasons that are only partly related to Afghanistan itself. Security officials say that Iran, in particular, is building up its position in the eventuality of a U.S. military intervention if Tehran does not end its military nuclear program..$^{49}$ This external convergence of interests could ultimately lead to the creation of a loose front against NATO, which would affect NATO as well as Pakistan's national interests.

From this perspective, the present situation in Afghanistan can be characterized as one of competing ambivalences. Iran, Russia, China, and the Central Asian republics would like NATO to leave but fear the resurgence of the Taliban, which would be likely to re-create a series of domestic problems for each of them. Other countries, particularly Pakistan, can tolerate the Taliban but have no interest in NATO's departure. The present equilibrium is therefore extremely unstable. Should the overall situation further deteriorate, Afghanistan could again become the location of a series of small proxy wars as it had been for years before the U.S. intervention in October 2001.

In the short term, Pakistan's diplomatic skills and interventionism in Afghanistan constrain NATO, which is now willing to establish a liaison office in Islamabad. All forces willing to contribute to Afghanistan's stability and the fight against the Taliban seek Islamabad's support. All, including NATO, are dependent on Pakistan. Pakistan provides Western forces, in particular NATO forces, with logistical support while it retains its ability to harass Western troops through its Taliban proxies. Following the practice of plausible deniability, Pakistan calibrates the frequency, scope, and intensity of the attacks according to the political necessities of the moment.

This maneuver is doubly rewarded. The alliance with the United States against Al Qaeda will bring tangible benefits in the form of weapons sales. On July 13, 2006, the George W. Bush administration presented the U.S. Congress with its plan to sell Pakistan F-16 fighters in a deal worth $\$ 5$ billion. The deal would reportedly include eighteen new F-16 aircraft with an option to purchase another eighteen planes, a support package for twenty-six used F-16s, an ammunition package, and an upgrade package for the current fleet of thirty-four F-16s.

If the sale is approved by Congress, the Pakistani military will be comforted in its dual game strategy. Moreover, several countries with armaments industries will use the U.S. decision as a pretext to resume arms sales to Pakistan. Pakistan will ultimately obtain both weapons and additional legitimacy.

Ultimately, Pakistan has an additional margin of maneuver. As frustrating as the current situation may be, things would be even worse should Islamabad decide to relocate the Taliban to Afghanistan. Not only would NATO forces be under additional pressure, but Islamabad would be in a position 
to disengage itself militarily while continuing to manipulate the Taliban through its intelligence agencies. Such an evolution becomes more credible by the day as the security situation continues to deteriorate in the Afghan provinces adjacent to the border, making Afghan, NATO, and U.S. intervention more difficult and providing additional security to the Taliban, who are gradually increasing their control.

\section{PREPARING FOR A POST-U.S. AFGHANISTAN}

As a consequence of the rapid deterioration of the situation in Afghanistan, Pakistan is also preparing options in case the United States departs. Pakistani officials, who speak of the U.S.-led coalition as "occupation forces" in Afghanistan, are convinced that history will repeat itself and that the United States will sooner or later leave the region. Once the Americans are gone, NATO determination will fade and Afghanistan will be left to itself.

The United States has withdrawn approximately three thousand troops in the autumn of 2006, troops that have been replaced by a larger number from Britain, Canada, Australia, Romania, and Denmark..$^{50}$ The total force remains too small for the area it is supposed to cover because the force is burdened with multiple tasks. The replacement troops will inevitably constitute easy targets for the Taliban. Public opinion may force the governments involved to withdraw their troops if the casualties are too high.

The recent takeover of Garmser and Naway-e Barakzayi, two district capitals of Helmand province, by the Taliban does not augur well for the success of NATO's mission in southern Afghanistan, even though NATO was able to recapture the two. ${ }^{51}$ The Taliban tactic so far has been to attack where the NATO presence is weak, ${ }^{52}$ but they are now able to mass more and more fighters and launch large-scale raids. They will most likely take on NATO troops directly, thus increasing the number of casualties.

Should Western troops leave the country or reduce their number to a symbolic presence, the position of the Afghan government could well weaken. Pakistan would be faced with a political vacuum that it believes it would have to fill to prevent any other regional power from acquiring a predominant influence.

Ultimately, Pakistan appears almost ideally placed to answer to any eventuality in the near or even more distant future. Its agents can help vary the intensity of Taliban attacks and therefore pressure the Afghan government and U.S. and NATO forces at will, according to the needs of the moment, while it maintains the fiction that it is still committed to the war on terror, thus preserving its usefulness and maintaining its standing in an international community increasingly trapped by its own priorities and disconnected from the on-the-ground realities.

\section{CONCLUSION AND POLICY IMPLICATIONS}

A true normalization of relations between Afghanistan and Pakistan presupposes agreements on a number of geopolitical issues that could constitute the components of a so-called grand bargain with Pakistan. 
The success of the ongoing peace process between India and Pakistan is undoubtedly the first condition for the end of Pakistan's interference in Afghanistan. Whatever India's intentions-good or bad-in Afghanistan, they will feed Pakistani suspicions as long as the antagonism between the two countries persists. Islamabad will then intervene in its western neighbor's affairs.

Although both India and Pakistan bear responsibility for the relative stagnation of the negotiations, Pakistan remains the anti-status quo country. Islamabad has shown flexibility in the manner in which the status quo could or should be revised, but there is still no discernable change in Islamabad's ultimate objective. Similarly, as exposed by the October 2005 earthquake and the free hand given by Islamabad to radical Islamist groups to participate in the relief operations, which led to a series of bomb blasts in New Delhi, there is still no evidence that Pakistan has renounced terrorism as a way of solving the dispute over Kashmir. Pakistan cannot therefore claim that whatever action it eventually takes in Afghanistan is the result of a necessity that it has itself contributed to creating, at least in its present form.

Afghanistan should also play its part in the process. Islamabad cannot be expected to respect a border that Kabul does not recognize. Afghanistan has nothing to gain by maintaining pressure on the issue of the border created by the Durand Line. The border issue is politically very sensitive domestically and, irrespective of ethnic background or political affiliation, nobody in Kabul wants to be seen as giving up an inch of Afghan sovereignty. For several reasons, Afghanistan's recognition of the border would be a sign of political maturity and would deprive Pakistan's interventions of any legitimacy:

- The Afghan claim is simply unacceptable to Pakistan as it would jeopardize its very existence. The NWFP accounts for 20 percent of Pakistan's territory, and ceding it to Afghanistan would open a Pandora's Box and raise, once again, doubts about the viability of Pakistan. Given the ongoing nationalist insurgency in Balochistan, the argument is particularly sensitive today.

- Afghanistan may be tempted to believe that it has nuisance capabilities that could be used against Pakistan, but engaging in a policy of tit for tat with Islamabad would ultimately prove more destructive for Kabul.

- Although it would undoubtedly satisfy Pashtun nationalists, changing the border would alter the demographic balance of Afghanistan and exacerbate other groups' resentment of Pashtun political dominance.

- Pakistani Pashtuns would not be willing to be merged in a greater Afghan entity.

- Recognizing the border would not truly separate Pashtuns of both countries. The border is porous and Pashtun populations have always migrated from one side to the other according to the needs of their herds.

The international community could and should guarantee an agreed border. The work of the existing tripartite commission (which actually includes four parties: Afghanistan, Pakistan, the United States, and NATO) that focuses on the delimitation of the border and the mechanisms of supervising its respect by all parties is certainly a step in the right direction. But this effort will produce lasting, meaningful results only if a political agreement can be obtained on the recognition of whatever delineation of the border will be decided. 
To be sure, the problem goes much beyond the border issue. It is clear that the continued presence of the international community in Afghanistan is necessary. First, the Afghan government is unlikely to fall as long as the International Security Assistance Force (ISAF) and NATO are present in the country. This presence will ensure that the Afghan domestic power game remains within acceptable limits and does not degenerate once more into a civil war. This has been understood by the Taliban, who are increasingly convinced that U.S. forces might not stay beyond the end of Bush's term and are trying to discourage the non-U.S. components of NATO from moving into southern Afghanistan.

Such a long-term presence will be possible only if the United States and the international community active in the region are able to avoid the trap set by Pakistan's leadership. Pakistan needs the international presence much more than the international community needs Pakistan; it is Pakistan's best security guarantee in Afghanistan and in the region. It should therefore be conditioned on a code of verifiable good conduct from Islamabad.

Ultimately, normalization of relations between Afghanistan and Pakistan hinges on democratizing Pakistan. Barnett Rubin has written: "Military domination of the Pakistani state is the problem." ${ }^{53}$ For years, the Pakistani army has sponsored Islamist groups in Kashmir and, with the support of the United States, in Afghanistan and has therefore aggravated the problem, not helped to solve it. Convergence of interests, not ideology, drove these relations. Islamists were seen by the West as an antidote to communism and by Pakistan as a counterweight to Pashtun nationalism. True, this support was initiated by Zulfikar Ali Bhutto, but in a defensive perspective, to counter an aggressive Muhammad Daoud. Afghanistan was also considered by both the West and by Pakistan as a useful buffer, offering Pakistan additional strategic depth against the Soviet Union. Once the military in Pakistan gained power, all attempts to propose a settlement of the situation and recognize the Durand Line, be it by Daoud or his Communist successors, Noor Muhammad Taraki and Hafizullah Amin, were rejected.

The Soviet invasion gave Pakistan's military the opportunity to reverse the concept: to acquire additional strategic depth, vis-à-vis India this time, through the control of Afghanistan. The almost concomitant end of both the Cold War and the Soviet invasion of Afghanistan did not change the perspective. The new concept-despite its wide discussion and promotion by two military men, former director general of the ISI Hamid Gul and former chief of army staff Aslam Beg, it was never an official policy of the Pakistani state-made little military sense but clearly indicated Pakistan's willingness to control its weaker neighbor. Hence, Pakistan supported the Taliban and their allies. Musharraf's reversal was essentially a temporary adjustment "to regain U.S. trust and support." 54

Only the end of military rule in Pakistan could possibly end the confrontation with India and calm the situation on the Afghan border. The study of the conditions that could possibly lead to a military withdrawal from political power is outside the scope of the present paper, but the end of the military's political power would undoubtedly constitute an essential component of any attempt to stabilize not only Afghanistan but the entire region in a sustainable manner. Democratizing Pakistan is not an intellectual and moral luxury, it is first and foremost a strategic imperative. 


\section{NOTES}

Nation (Pakistan), May 20, 2006.

Dawn (Pakistan), May 19, 2006.

Author interview, Kabul, May 2006.

Dawn, March 10, 2006.

Marvin G. Weinbaum, Afghanistan and Its Neighbors: An Ever Dangerous Neighborhood, Special Report no. 162 (Washington, D.C.: United States Institute of Peace, June 2006), p. 10.

6 Ibid.

$7 \quad$ Lt. Gen. Asad Durrani, “Whither Strategic Depth?” Nation/Post (Pakistan), May 27, 2006.

$8 \quad$ Robert Kaplan, “The Taliban's Silent Partner,” New York Times, July 20, 2006.

9 Ibid.

10 Frontier Post (Pakistan), May 20, 2006.

11 Post (Pakistan), May 20, 2006.

12 Daily Mail (Pakistan), May 7, 2006.

13 For the article on the British ban on the Baloch Liberation Army, see "Four Groups Banned under Anti-Terrorism Law," Reuters, July 17, 2006, <news.scotsman.com/latest.cfm?id=1041072006>; for the article on the arrest of the Taliban, see "Pakistan Arrests Scores of Militants in Crackdown," Reuters, July 18, 2006, <http://today.reuters.com/news/articlenews. aspx?type=worldNews\&storyID=2006-07-18T121103Z_01_SP248576_RTRUKOC_0_US-PAKISTAN-TALIBAN. xml\&pageNumber=0\&imageid $=\&$ cap $=\& s z=13 \&$ WTModLoc $=$ NewsArt-C1-ArticlePage2 $>$.

14 Nation, May 20, 2006.

15 See, for example, Shamsa Ishfaq, "No Taliban Sanctuaries in Pakistan," Daily Mail, May 9, 2006, which repeats, against all evidence, the arguments of the Ministry of Foreign Affairs.

${ }_{16}$ Rahimullah Yousoufzai, "No End in Sight," Newsline, April 2006, p. 27.

17 Zahid Hussain, "Terror in Miranshah,” Newsline, April 2006, p. 23.

18 Intikhab Amir, “Waziristan: No Man's Land?” Herald, April 2006, p. 77.

19 Ibid.

20 Kaplan, "The Taliban's Silent Partner."

${ }^{21} \quad$ News (Pakistan), February 15, 2006.

22 See Syed Talat Husain, “Zero-Sum Game," Newsline, April 2006, p. 33.

${ }_{23}$ Dawn, February 18, 2006.

24 Ibid.

25 Fazal-ur Rahim Marwat, “The Durand Line Issue," Frontier Post, October 17, 2003.

26 Vasili Safronchuk, "Afghanistan in the Amin Period," Mezhdunarodnaya Zhizn [International Affairs], no. 2 (February 1991): pp. 79-96.

27 Ibid.

28 Gilles Dorronsoro, Revolution Unending: Afghanistan: 1979 to the Present (London: Hurst, 2005), p. 320.

29 Author interviews, May 2006.

30 On the definition of Pashtunistan, see Kulwand Kaur, Pak-Afghanistan Relations (New Delhi: Deep \& Deep Publications, 1985), p. 45.

31 Post, May 20, 2006.

32 Weinbaum, Afghanistan and Its Neighbors, p. 9.

33 "Afghanistan: The Problem of Pashtun Alienation," Asia Report no. 62 (Kabul/Brussels: International Crisis Group, August 5, 2003), <www.crisisgroup.org/library/documents/report_archive/A401078_05082003.pdf>.

34 Ibid.

35 Hindu (India), July 28, 2003.

36 Scott Baldauf, "India-Pakistan Rivalry Reaches into Afghanistan," Christian Science Monitor, September 12, 2003, <www.csmonitor.com/2003/0912/p07s01-wosc.html>.

37 Ibid. 
Herald (Karachi, Pakistan), September 2004.

39 Shaiq Hussain, "Pakistan to Ask India to Rein in Afghan Consulates," Nation, March 18, 2006, <www.nation.com.pk/daily/mar-2006/18/index11.php>.

40 Ibid.

${ }^{41}$ Gaurang Batt, "'RAW Is Training 600 Baluchis in Afghanistan': Mushahid Hussain,” Boloji.com, May 14, 2006, $<$ www.boloji.com/analysis2/0116.htm>.

42 Ibid.

43 Ibid.

44 Durrani, "Whither Strategic Depth?"

45 Batt, "RAW Is Training 600 Baluchis in Afghanistan'."

46 "Pak Fears Indian Army's Afghan Entry," IBNLive.com, July 7, 2006, <http://in.news.yahoo.com/060707/211/ $65 \mathrm{p} 30$. html.

47 Nation, July 6, 2006.

48 Amir, "Waziristan: No Man's Land?" p. 79.

49 Author interview, Kabul, May 2006.

so Economist, June 10-16, 2006.

${ }_{51} \quad$ "Operation Preparing to Retake Southern Afghan Districts," Radio Free Europe-Radio Liberty, July 18, 2006, <www.rferl.org/featuresarticle/2006/07/11EC916B-BE15-4C3D-B849-ECEEE5CBAF25.html>.

$52 \quad$ Ibid.

53 Barnett R. Rubin, "Afghanistan's Uncertain Transition from Turmoil to Normalcy," CSR no. 12 (New York: Council on Foreign Relations, Center for Preventive Action, March 2006), p. 13, <www.cfr.org/content/publications/attachments/ Afghanistan_CSR.pdf>.

54 Husain Haqqani, Pakistan: Between Mosque and Military (Washington, D.C.: Carnegie Endowment for International Peace, 2005), p. 262. 
p 


\section{ABOUT THE CARNEGIE ENDOWMENT}

The Carnegie Endowment for International Peace is a private, nonprofit organization dedicated to advancing cooperation between nations and promoting active international engagement by the United States. Founded in 1910, Carnegie is nonpartisan and dedicated to achieving practical results.

Through research, publishing, convening, and, on occasion, creating new institutions and international networks, Endowment associates shape fresh policy approaches. Their interests span geographic regions and the relations between governments, business, international organizations, and civil society, focusing on the economic, political, and technological forces driving global change.

Through its Carnegie Moscow Center, the Endowment helps to develop a tradition of public policy analysis in the former Soviet Republics and to improve relations between Russia and the United States. The Endowment publishes Foreign Policy, one of the world's leading magazines of international politics and economics, which reaches readers in more than 120 countries and in several languages.

For more information, visit www.CarnegieEndowment.org.

The South Asia Project is home to an assortment of scholars from around the world, giving global perspective to the issues facing this increasingly important region: India's growth as a new global nuclear power and the U.S. grand strategy toward India; progressive reform in Pakistan and recommendations for Western governments toward such reform; energy, economic, and political-security strategies for the United States and India; and overall nuclear security issues in South Asia.

This region touches other areas of the Carnegie Endowment, including the Trade, Equity, and Development Project, which has a special interest in how India's agricultural and textile sectors would be affected by global trade liberalization. As well, Carnegie's Nuclear Non-proliferation Project offers extensive data, news, and other resources on South Asia and nuclear weapons on its website, www.ProliferationNews.org.

For more information about Carnegie's South Asia Project, visit www.CarnegieEndowment.org/SouthAsia. 


\section{Carnegie Papers}

\section{6}

72. Pakistan-Afghanistan Relations in the Post-9/11 Era (F. Grare)

71. Morocco: From Top-Down Reform to Democratic Transition? (M. Ottaway and M. Riley)

70. Islam, Militarism, and the 2007-2008 Elections in Pakistan (F. Grare)

69. Reform in Syria: Steering between the Chinese Model and Regime Change

68. The Saudi Labyrinth: Evaluating the Current Political Opening (A. Hamzawy)

67. Islamist Movements and the Democratic Process in the Arab World (N. Brown, A. Hamzawy, and M. Ottaway)

66. Evaluating Egyptian Reform (M. Dunne)

65. Pakistan: The Resurgence of Baluch Nationalism (F. Grare)

64. Lebanon: Finding a Path from Deadlock to Democracy (J. Choucair)

\section{5}

63. The Dangers of Political Exclusion: Egypt's Islamist Problem (B. Kodmani)

62. Why Did the Poorest Countries Fail to Catch Up? (B. Milanovic)

61. Legalism Sans Frontières? U.S. Rule-of-Law Aid in the Arab World (D. Mednicoff)

60. The Complexity of Success: The U.S. Role in Russian Rule of Law Reform (M. Spence)

59. Evaluating Palestinian Reform (N. Brown)

58. Judicial Reform in China: Lessons from Shanghai (V. Hung)

57. Lessons Not Learned: Problems with Western Aid for Law Reform in Postcommunist Countries (W. Channell)

56. Evaluating Middle East Reform: How Do We Know When It Is Significant? (M. Ottaway)

55. Competing Definitions of the Rule of Law: Implications for Practitioners (R. Belton)

\section{4}

54. E.U.-Russia Relations: Interests and Values-A European Perspective (R. Schuette)

53. The Political-Economic Conundrum: The Affinity of Economic and Political Reform in the Middle East and North Africa (E. Bellin)

52. Political Reform in the Arab World: A New Ferment? (A. Hawthorne)

51. Cambodia Blazes a New Path to Economic Growth and Job Creation (S. Polaski)

50. Integrating Democracy Promotion into the U.S. Middle East Policy (M. Dunne)

49. Islamists in the Arab World: The Dance around Democracy (G. Fuller)

48. Democracy and Constituencies in the Arab World (M. Ottaway)

47. Development and Foreign Investment: Lessons Learned from Mexican Banking (J. Steinfeld)

46. Deterring Conflict in the Taiwan Strait: The Successes and Failures of Taiwan's Defense Reform and Modernization Program (M. Swaine)

45. Europe's Uncertain Pursuit of Middle East Reform (R. Youngs)

44. Middle Eastern Democracy: Is Civil Society the Answer? (A. Hawthorne)

43. Small Enterprises and Economic Policy (A. Åslund, S. Johnson)

42. Women's Rights and Democracy in the Arab World (M. Ottaway)

\section{3}

41. Beyond Rule of Law Orthodoxy: The Legal Empowerment Alternative (S. Golub)

40. Strengthening Linkages between U.S. Trade Policy and Environmental Capacity Building (J. Audley, V. Ulmer)

39. Is Gradualism Possible? Choosing a Strategy for Promoting Democracy in the Middle East (T. Carothers)

For a complete list of Carnegie Papers, go to www.CarnegieEndowment.org/pubs. 